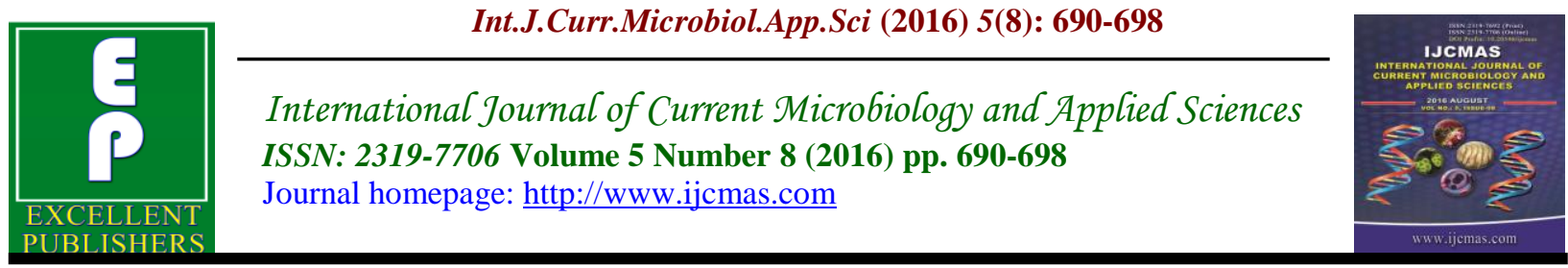

Original Research Article

http://dx.doi.org/10.20546/ijcmas.2016.508.078

\title{
Economic Evaluation of Finger Millet under different Nutrient Management Practices
}

\author{
Ch. Pallavi ${ }^{1 *}$, B. Joseph ${ }^{2}$, M.A. Aariff $\mathrm{Khan}^{3}$ and S. Hemalatha ${ }^{4}$ \\ ${ }^{1}$ Department of Agronomy, College of Agriculture, Professor Jayashankar Telangana State \\ Agricultural University, Rajendranagar, Hyderabad -500030, Telangana State, India \\ ${ }^{2}$ Principal Scientist (Agronomy) and Head, RS \& RRS, Rudrur, University officers quarter \\ No.1, PJTSAU campus, Rajendranagar, Hyderabad, 500030, Tealngana state, India \\ ${ }^{3}$ Principal Scientist (Soil Science), AICRP on Agroforestry, PJTSAU campus, Rajendranagar, \\ Hyderabad, 500030, Telangana State, India \\ ${ }^{4}$ Principal Scientist (Agronomy), Farmers Call Centre, ANGRAU, India \\ *Corresponding author: pallavireddy8990@gmail.com
}

Keywords

Economics, agri-sliviculture, nutrient management, finger millet, Melia azedarach.

\section{Article Info}

Accepted:

28 July 2016

Available Online:

10 August 2016

\section{A B S T R A C T}

Finger millet was grown under three year old Melia azedarach in red sandy loam soil with different management options viz., application of FYM @ $10 \mathrm{t} \mathrm{ha}^{-1}, 100 \%$ RDF (40:20:20 NPK kg ha ${ }^{-1}$ ) alone, and in conjunction with 75\% RD N with $25 \%$ $\mathrm{N}$ through FYM, Vermicompost, Poultry manure; also with biofertilizers @ $5 \mathrm{~kg}$ $\mathrm{ha}^{-1}$ Azospirillum and PSB along with finger millet alone as sole cropping with $100 \%$ RDF.The highest grain $\left(2681 \mathrm{~kg} \mathrm{ha}^{-1}\right)$ and straw yield $\left(5063 \mathrm{~kg} \mathrm{ha}^{-1}\right)$ resulted with sole crop on par with $75 \% \mathrm{RD} \mathrm{N}+25 \% \mathrm{~N}$ poultry manure $(2405$ and $4733 \mathrm{~kg}$ $\mathrm{ha}^{-1}$ ) and $100 \%$ RDF (2393 and $\left.4745 \mathrm{~kg} \mathrm{ha}^{-1}\right)$. The lowest grain $\left(1583 \mathrm{~kg} \mathrm{ha}^{-1}\right)$ and straw yield (3402 $\left.\mathrm{kg} \mathrm{ha}^{-1}\right)$ was found with control FYM @ $10 \mathrm{t} \mathrm{ha}^{-1}$ i.e., farmers practice. Gross monetary returns ( $\left(₹ 42,747 \mathrm{ha}^{-1}\right)$, net monetary returns ( $(₹ 26,987 \mathrm{ha}$ ${ }^{1}$ ) and $\mathrm{B}: \mathrm{C}$ ratio (2.71) were highest with sole crop followed by $100 \% \mathrm{RDF}$ and $75 \% \mathrm{RD} \mathrm{N}+25 \% \mathrm{~N}$ poultry manure compared to other treatment combinations. Among nutrient management practices tested, $75 \% \mathrm{RD} \mathrm{N}+25 \% \mathrm{~N}$ poultry manure and $100 \% \mathrm{RDF}$ in agri-silvi culture system was better for realizing higher grain yield, straw yield and economic returns apart from sustaining better soil nutrient status on sandy loam soils of Southern Telangana region of Andhra Pradesh.

\section{Introduction}

Finger millet (Eleusine coracana L.) is an important small millet crop grown in India and has the pride of place in having highest productivity among millets. It is also known as ragi, African millet and bird's foot millet and an important staple food crop in part of eastern and central Africa and India. Grain is higher in protein, fat and minerals than rice, corn or sorghum. When consumed as food it provides a sustaining diet, especially for people doing hard work. Straw makes valuable fodder for both working and milking animals. Grain may also be malted and a flour of the malted grain used as cakes 
or porridge and a nourishing food for infants and invalids. Finger millet is considered an especially wholesome food for diabetics.

In India, finger millet is cultivated in an area of $1.14 \mathrm{~m}$ ha with a production of $1.69 \mathrm{~m}$ tand an average productivity of $1483 \mathrm{~kg} \mathrm{ha}^{-1}$. In Andhra Pradesh, it covers an area of 0.42 lakh ha with a production of 0.50 lakh $\mathrm{t}$ at an average productivity of $1179 \mathrm{~kg} \mathrm{ha}^{-1}$ (Department of Agriculture and Cooperation, 2014).

Modern management practices rely on chemical fertilizers and pesticides that have led to decline in soil organic matter, increased soil erosion and pollution of surface and ground water (Singh, 2000 and Relyea, 2005). The low productivity and risk are the other problem in the arable cropping system. High production cost and reliance on loans to purchase inputs are the major risks especially in rainfed areas where yields are uncertain (Eyhorn et al., 2007).

Agroforestry is an appropriate and efficient land use system in dry lands, for site improvement and also for optimization of productivity of agricultural crops as well as forest crops. Cultivation of finger millet (Eleusine coracana L.) as one of the multipurpose intercrops in the alleys of young plants of Melia is desirable to maximize the dry lands and space use efficiency to generate supplemental income during the initial juvenile phase of Melia silviculture system. In view of diversity of the problems in rainfed areas, an integrated approach of land management to utilize the natural resources more efficiently in dryland agriculture is essential to meet the requirements of farming community and their deteriorating livestock, both to enhance the land productivity and also to generate continuous and stable income. In order to achieve an intensive production of grain and good quality of finger millet in low fertile red sandy loam soils, it is necessary to follow simultaneously all management practices through integrated nutrient management to sustain the productivity and to improve the soil fertility. So, under these circumstances it is imperative to study the various nutrient sources like organic manures, biofertilizers along with chemical fertilizer to better understand the resource use efficiencies particularly of economic efficiency.

\section{Materials and Methods}

\section{Experimental site}

Field experiment was conducted with finger millet variety (PRS-2) at agroforestry research block, Acharya N.G Ranga Agricultural University campus, Rajendranagar, Hyderabad during kharif, 2013. The weekly mean maximum temperature during the crop growth period ranged from 27.8 to $33.5^{\circ} \mathrm{C}$ with an average of $30.5^{\circ} \mathrm{C}$, while the weekly mean minimum temperature ranged from $17.7^{\circ} \mathrm{C}$ to $25.0^{\circ} \mathrm{C}$ with an average of $21.6^{\circ} \mathrm{C}$. The total rainfall received during the crop growth period was $437.1 \mathrm{~mm}$ distributed in 30 rainy days. The experimental soil was Alfisol with sandy loam texture with $\mathrm{pH}$ (7.57), EC (0.195 $\left.\mathrm{dSm}^{-1}\right)$ and $\mathrm{OC}(0.75 \%)$. The soil was medium in available nitrogen $(259.2 \mathrm{~kg} \mathrm{ha}$ ${ }^{1}$ ), phosphorus (40.85 kg ha ${ }^{-1}$ ) and high in available potassium $\left(352.1 \mathrm{~kg} \mathrm{ha}^{-1}\right)$. The experiment was laid out in a Randomized Block Design and replicated thrice with 9 treatments comprised of $\mathrm{T}_{1} \mathrm{FYM} 10 \mathrm{t} \mathrm{ha}^{-1}$, $\mathrm{T}_{2} 100 \%$ RDF (40:20:20 - N: $\mathrm{P}_{2} \mathrm{O}_{5}: \mathrm{K}_{2} \mathrm{O} \mathrm{kg}$ $\left.\mathrm{ha}^{-1}\right), \mathrm{T}_{3} 75 \%$ RD N + 25\% N through FYM, $\mathrm{T}_{4} 75 \% \mathrm{RD} \mathrm{N}+25 \% \mathrm{~N}$ Vermicompost, $\mathrm{T}_{5}$ $75 \% \mathrm{RD} \mathrm{N}+25 \% \mathrm{~N}$ Poultry manure, $\mathrm{T}_{6}$ $75 \%$ RD N + Azospirillum @ $5 \mathrm{~kg} \mathrm{ha}^{-1}, \mathrm{~T}_{7}$ $75 \%$ RD N + PSB @ 5 kg ha ${ }^{-1}, \mathrm{~T}_{8} 75 \%$ RD $\mathrm{N}+$ Azospirillum + PSB @ $5 \mathrm{~kg} \mathrm{ha}^{-1}$ and $\mathrm{T}_{9}$ Sole crop without trees. The other package 
of practices used recommended for raising the crop.

\section{Biometric and yield observations}

Five plants in each plot were selected at random and tagged. These plants were used for recording biometric observation at different stages of crop growth. The harvested produce from each net plot was threshed, sun dried, winnowed separately and the finger millet grain yield was recorded at $14 \%$ moisture content and expressed in $\mathrm{kg} \mathrm{ha}^{-1}$ (Watson, 1947).Plant height was measured with a wooden scale from the base of the plant to the tip of growing point at harvest. The observations were taken from the ten earmarked plants and mean value was expressed in $\mathrm{cm}$.

\section{Leaf area index (LAI)}

Leaf area was estimated on two plants in each plot at 30, 45, 60, 75 DAS and at harvest stages. The area of total leaves was measured with digital leaf area meter (LI3100) and expressed in $\mathrm{cm}$. Leaf area index was calculated by using the formula as proposed by Watson (1952).

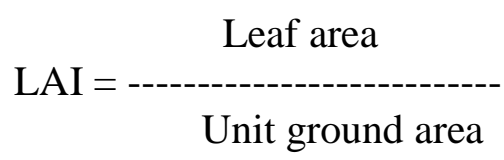

\section{Economics}

The cost of cultivation for each treatment was worked out. Similarly, gross returns were calculated based on current market price of the produce. The net returns were obtained after deducting the cost of cultivation from gross returns. Later, the benefit-cost ratio was worked out by using the formula:

$$
\mathrm{B}: \mathrm{C}=\frac{\text { Gross returns }}{--------------}
$$

\section{Statistical Analysis}

The data on various characters studied during the course of investigation were statistically analysed for randomized block design. Wherever treatment differences were significant ("F" test), critical differences were worked out at five per cent probability level. Treatment differences that were not significant were denoted as "NS".

\section{Results and Discussion}

\section{Plant height}

Plant height of finger millet at harvest ranged from 78.6-94.8 $\mathrm{cm}$ with a mean 88.7 $\mathrm{cm}$. Different treatments significantly influenced over control i.e. FYM @ $10 \mathrm{t} \mathrm{ha}^{-}$ 1. The data on plant height revealed that, the plant height increased progressively with different sources of N. However, among the nitrogen sources sole crop without trees has produced the taller plants $(94.8 \mathrm{~cm})$ on par with $100 \%$ RDF $(91.3 \mathrm{~cm})$ and $75 \%$ RD N + $25 \% \mathrm{~N}$ poultry manure $(91.1 \mathrm{~cm})$ followed by $75 \% \mathrm{RD} \mathrm{N}+25 \% \mathrm{~N}$ vermicompost $(90.4 \mathrm{~cm})$.

Among biofertilizers, on par height was obtained over control with shorter plants $(78.6 \mathrm{~cm})$ at harvest. The increased availability of nutrients in the soil through mineralization of organic sources could have triggered cell elongation and multiplication resulting in high growth rate of shoots in turn plant height of finger millet over control. Combination of organics and inorganics which ensured ready availability of nutrients at initial stages of crop is due to improved soil properties and long term nutrient availability through organics. Similar results were obtained by Sunitha et al., (2004), Narolia et al., (2009) and Giribabu et al., (2010). 


\section{Leaf area index (LAI)}

The mean LAI at harvest was 2.82. The LAI was significantly influenced by different treatments over control. Among different nitrogen sources at harvest in agri-silvi culture system, sole crop had shown higher LAI (3.43) at harvest followed by $75 \% \mathrm{RD}$ $\mathrm{N}+25 \% \mathrm{~N}$ vermicompost (3.12), $75 \% \mathrm{RD}$ $\mathrm{N}+25 \% \mathrm{~N}$ poultry manure (3.09), $75 \% \mathrm{RD}$ $\mathrm{N}+$ Azospirillum + PSB (2.91) and 100\% RDF (2.90). Highest LAI might be due to more light interception and enhanced photosynthetic rate (NAR), which ultimately resulted in higher dry matter production, straw yield, test weight, grain weight earhead $^{-1}$ and grain yield. These are in conformity with the findings of Patil et al. (2003) in sweet sorghum. He also observed relationship with leaf area and distribution of sugars and starch into stem and grain in sweet sorghum cultivars as LAI play crucial role in enhancing the photosynthetic assimilation.

\section{Grain and Straw yield}

Grain and straw yield significantly affected by the judicious use of inorganic fertilizer with organic manures, Poultry manure, Vermicompost, FYM and biofertilizers i.e., Azospirillum and PSB (Table1). The highest grain yield $\left(2681 \mathrm{~kg} \mathrm{ha}^{-1}\right)$ was recorded with sole crop on par with $75 \%$ RD N $(2405 \mathrm{~kg}$ $\left.\mathrm{ha}^{-1}\right)+25 \% \mathrm{~N}$ through poultry manure $\left(2394 \mathrm{~kg} \mathrm{ha}^{-1}\right)$ and $100 \%$ RDF significantly superior over $75 \% \mathrm{RD} \mathrm{N}+25 \% \mathrm{~N}$ through vermicompost and $75 \% \mathrm{RD} \mathrm{N}+$ Azospirillum + PSB. The percentage increase in grain yield with sole crop, $75 \%$ RD N $+25 \% \mathrm{~N}$ poultry manure and $100 \%$ RDF over control was $65.39 \%, 48.37 \%$ and $47.69 \%$ respectively. Among the nutrient biofertilizers combination treatments also performed better than control where only FYM @ $10 \mathrm{t} \mathrm{ha}^{-1}$ was applied. Among them $75 \%$ RD N + Azospirillum + PSB $(2126 \mathrm{~kg}$ $\mathrm{ha}^{-1}$ ) was significantly superior to control $\left(1621 \mathrm{~kg} \mathrm{ha}^{-1}\right)$. In terms of percentage, the increase of 34.30, 24.89 and $23.44 \%$ with 75\% RD N + Azospirillum + PSB, 75\% RD $\mathrm{N}+$ Azospirillum and $75 \% \mathrm{RD} \mathrm{N}+\mathrm{PSB}$ respectively (Figure 1and 2).

Finger millet as sole crop $\left(5063 \mathrm{~kg} \mathrm{ha}^{-1}\right)$ resulted on par yields with $100 \%$ RDF (4745 $\mathrm{kg} \mathrm{ha}^{-1}$ ) and $75 \% \mathrm{RD} \mathrm{N}+25 \% \mathrm{~N}$ through poultry manure $\left(4733 \mathrm{~kg} \mathrm{ha}^{-1}\right)$ significantly superior over $75 \% \mathrm{RD} \mathrm{N}+25 \% \mathrm{~N}$ through vermicompost (4377 $\left.\mathrm{kg} \mathrm{ha}^{-1}\right)$ and $75 \% \mathrm{RD}$ $\mathrm{N}+$ Azospirillum + PSB $\left(4241 \mathrm{~kg} \mathrm{ha}^{-1}\right)$. The percentage increase in grain yield with sole crop, $75 \% \mathrm{RD} \mathrm{N}+25 \% \mathrm{~N}$ through poultry manure and $100 \%$ RDF over control was $48.82 \%, 39.12 \%$ and $39.12 \%$ respectively.

The conjunctive use of organic and inorganic sources has beneficial effect on physiological process of plant metabolism and growth, there by leading to higher grain yield. The easy availability of nitrogen due to mineralization of organics there by influence the shoot and root growth favouring absorption of other nutrients. Similar results were obtained by Varalakshmi et al., (2005), Yakadri and Reddy (2009), Umesh et al., (2006), Basavaraju and Purushotham (2009). Reduced yield in finger millet compared to sole crop may be ascribed due to competition for light, moisture and nutrients with suppressing effect on crops, reduced solar radiation on crop canopy. Similar results were reported by Deswal and Nandal (2008), Prasad et al., (2011) and Kumar et al., (2013).

\section{Economics}

The conjoint use of organic and inorganic sources of nitrogen progressively increased the net returns and $\mathrm{B}: \mathrm{C}$ ratio of finger millet crop. The gross returns, net returns and B:C ratio ranged ₹ 42,747 to ₹ $25,446 \mathrm{ha}^{-1}$, ₹ 26,987 to $₹ 5,846 \mathrm{ha}^{-1}$ and 2.71 to 1.30 respectively (Table 2). 
Table.1 Plant height, LAI and yield of finger millet as influenced by nutrient management in Melia azedarach based agri-silvi system

\begin{tabular}{|c|c|c|c|c|}
\hline Treatments & $\begin{array}{c}\text { Plant } \\
\text { height }(\mathrm{cm})\end{array}$ & LAI & $\begin{array}{c}\text { Grain yield } \\
\quad\left(\mathrm{kg} \mathrm{ha}^{-1}\right)\end{array}$ & $\begin{array}{l}\text { Straw yield } \\
\left(\mathrm{kg} \mathrm{ha}^{-1}\right)\end{array}$ \\
\hline $\mathrm{T}_{1} \mathrm{FYM} @ 10 \mathrm{tha}^{-1}$ & 78.6 & 1.82 & 1583 & 3402 \\
\hline $\mathrm{T}_{2} 100 \% \mathrm{RDF}$ & 91.3 & 2.90 & 2393 & 4745 \\
\hline $\mathrm{T}_{3} 75 \% \mathrm{~N}+25 \% \mathrm{~N} \mathrm{FYM}$ & 84.0 & 2.57 & 1828 & 3745 \\
\hline $\mathrm{T}_{4} 75 \% \mathrm{RD} \mathrm{N}+25 \% \mathrm{~N}$ Vermicompost & 90.4 & 3.12 & 2216 & 4377 \\
\hline $\mathrm{T}_{5} 75 \% \mathrm{RD} \mathrm{N}+25 \% \mathrm{~N}$ Poultry manure & 91.1 & 3.09 & 2405 & 4733 \\
\hline $\mathrm{T}_{6} 75 \%$ RD N + Azospirillum & 89.7 & 2.81 & 1977 & 4014 \\
\hline $\mathrm{T}_{7} 75 \% \mathrm{RD} \mathrm{N}+\mathrm{PSB}$ & 87.6 & 2.73 & 1954 & 4006 \\
\hline $\mathrm{T}_{8} 75 \% \mathrm{RD} \mathrm{N}+$ Azospirillum + PSB & 90.8 & 2.91 & 2126 & 4241 \\
\hline $\mathrm{T}_{9}$ Sole crop without trees & 94.8 & 3.43 & 2681 & 5063 \\
\hline Mean & 88.7 & 2.82 & 2129 & 4258 \\
\hline S.Em \pm & 1.24 & 0.12 & 102 & 205 \\
\hline $\mathrm{CD}(\mathrm{P}=0.05)$ & 3.74 & 0.36 & 310 & 619 \\
\hline
\end{tabular}

Table.2 Yield and economics of finger millet as influenced by nutrient management in Melia azedarach based agri-silvi system

\begin{tabular}{|c|c|c|c|c|}
\hline Treatments & $\begin{array}{c}\text { Cost of } \\
\text { cultivation } \\
\left(₹ \text { ha }^{-1}\right)\end{array}$ & $\begin{array}{l}\text { Gross } \\
\text { return } \\
\left(₹ \mathbf{h a}^{-1}\right)\end{array}$ & $\begin{array}{l}\text { Net return } \\
\quad\left(₹ \mathbf{h a}^{-1}\right)\end{array}$ & B:C ratio \\
\hline $\mathrm{T}_{1}$ FYM @ $10 \mathrm{tha}^{-1}$ & 19600 & 25446 & 5846 & 1.30 \\
\hline $\mathrm{T}_{2} 100 \% \mathrm{RDF}$ & 14359 & 36268 & 21909 & 2.53 \\
\hline $\mathrm{T}_{3} 75 \% \mathrm{~N}+25 \% \mathrm{~N} \mathrm{FYM}$ & 16531 & 29293 & 12762 & 1.77 \\
\hline $\mathrm{T}_{4} 75 \% \mathrm{RD} \mathrm{N}+25 \% \mathrm{~N}$ Vermicompost & 17421 & 35427 & 18006 & 2.03 \\
\hline $\mathrm{T}_{5} 75 \% \mathrm{RD} \mathrm{N}+25 \% \mathrm{~N}$ Poultry manure & 17121 & 38442 & 21321 & 2.25 \\
\hline $\mathrm{T}_{6} 75 \%$ RD N + Azospirillum & 14621 & 31662 & 17041 & 2.17 \\
\hline $\mathrm{T}_{7} 75 \% \mathrm{RD} \mathrm{N}+\mathrm{PSB}$ & 14621 & 31313 & 16692 & 2.14 \\
\hline $\mathrm{T}_{8} 75 \%$ RD N + Azospirillum + PSB & 15021 & 34011 & 18990 & 2.26 \\
\hline $\mathrm{T}_{9}$ Sole crop without trees & 15760 & 42747 & 26987 & 2.71 \\
\hline
\end{tabular}

*Price of finger millet: ₹ $15 \mathrm{~kg}^{-1}$ grain

*Gross returns were calculated by multiplying grain yield with price of finger millet 
Fig.1 Grain yield of finger millet as influenced by nutrient management in Melia azedarach based agri-silvi system

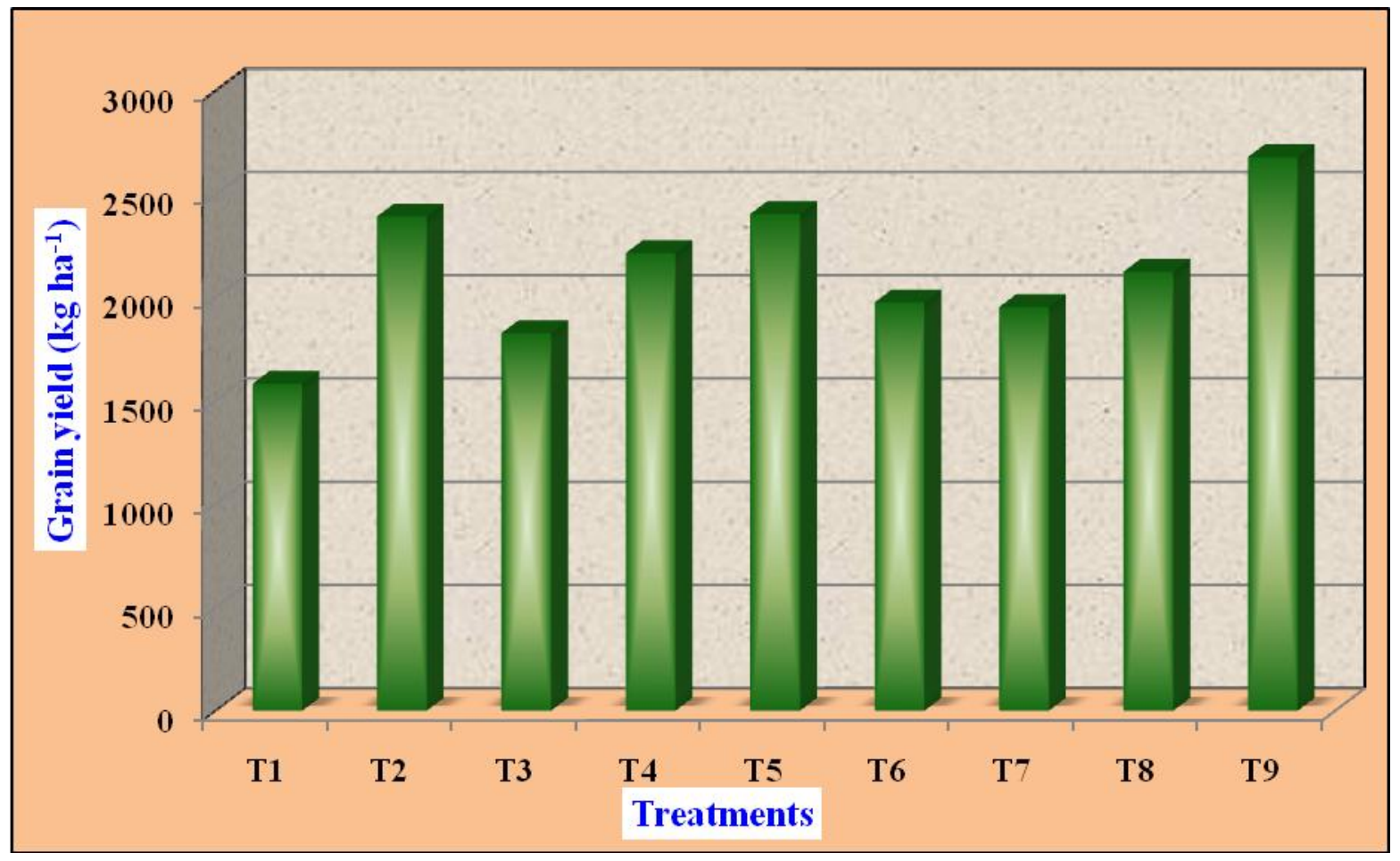

Fig.2 Straw yield of finger millet as influenced by nutrient management in Melia azedarach based agri-silvi system

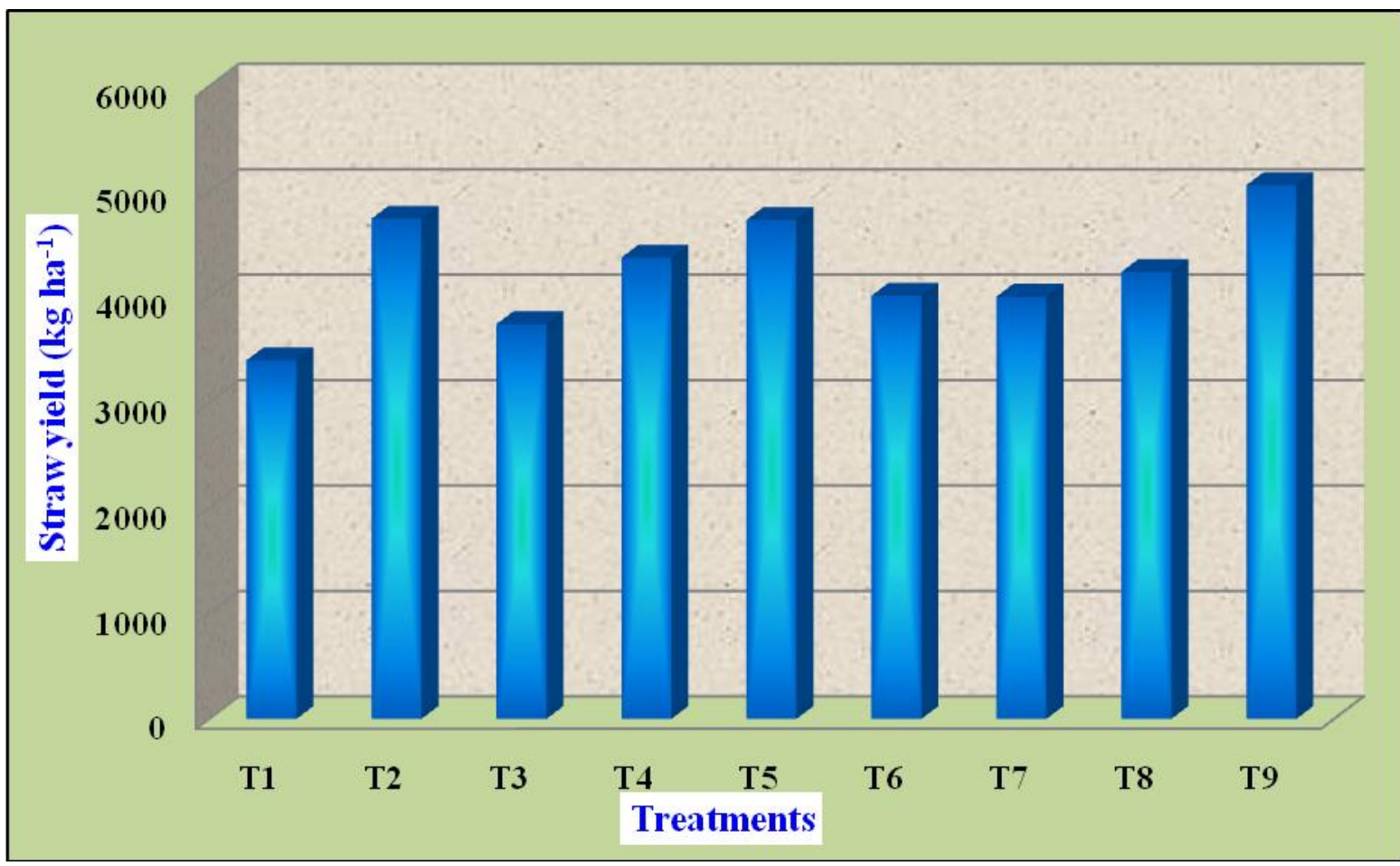


Fig.3 Gross returns and B:C of finger millet as influenced by nutrient management in Melia azedarach based agri-silvi system

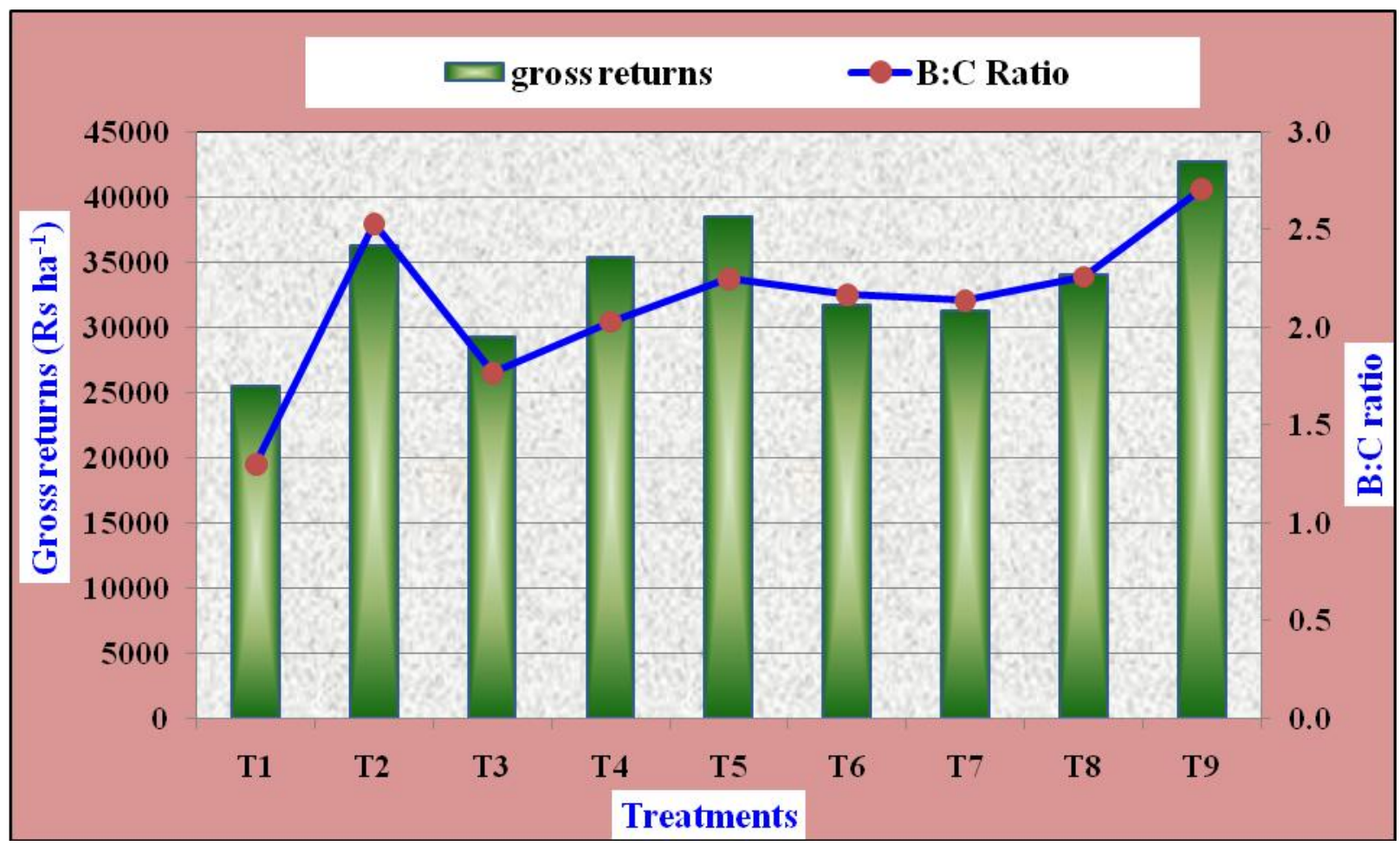

The highest gross returns ( $₹ 42,747 \mathrm{ha}^{-1}$ ) was recorded with sole crop followed by $75 \%$ $\mathrm{RD} \mathrm{N}+25 \% \mathrm{~N}$ poultry manure (₹ 38,442 ) $>100 \%$ RDF (₹ 36,268) > 75\% RD N + 25\% $\mathrm{N}$ vermicompost $(₹ 35,427)>75 \% \mathrm{RD} \mathrm{N}+$ Azospirillum + PSB (₹ 34,011) >75\% RD N + Azospirillum $>75 \%$ RD N + PSB > 75\% RD N $+25 \% \mathrm{~N}$ FYM. The highest net returns (₹ 26,987 $\mathrm{ha}^{-1}$ ) was recorded with sole cropfollowed by $100 \%$ RDF (₹ 21,909 $\mathrm{ha}^{-1}$ ) $75 \% \mathrm{RD} \mathrm{N}+25 \% \mathrm{~N}$ poultry manure (₹ 21,321 $\mathrm{ha}^{-1}$ ) > 75\% RD N + Azospirillum + PSB (₹ $\left.18,990 \mathrm{ha}^{-1}\right)>75 \% \mathrm{RD} \mathrm{N}+25 \% \mathrm{~N}$ vermicompost $>75 \%$ RD N + Azospirillum > $75 \% \mathrm{RD} \mathrm{N}+\mathrm{PSB}>75 \% \mathrm{RD} \mathrm{N}+25 \% \mathrm{~N}$ FYM (Figure 3). The highest $\mathrm{B}: \mathrm{C}$ ratio (2.71) was recorded with sole crop followed by $100 \%$ RDF (2.53), $75 \%$ RD N + Azospirillum + PSB (2.26), 75\% RD N + $25 \% \mathrm{~N}$ poultry manure $(2.25)>75 \% \mathrm{RD} \mathrm{N}$ $+25 \% \mathrm{~N}$ vermicompost > 75\% RD N + Azospirillum $>75 \%$ RD N + PSB > 75\% RD
$\mathrm{N}+25 \% \mathrm{~N}$ FYM. The control treatment registered the lowest gross returns ( $₹ 25,446$ $\mathrm{ha}^{-1}$ ), net returns ( $₹ 5,846 \mathrm{ha}^{-1}$ ) and $\mathrm{B}: \mathrm{C}$ ratio (1.30).

Higher level of biomass accumulation and efficient translocation to the reproductive parts due to supply of adequate nutrients might be responsible for the production of elevated yield attributes, which resulted in higher monetary returns and $\mathrm{B}: \mathrm{C}$ ratio. The lower income obtained in agri-silvi system compared to sole cropping system could be compensated by income from Melia trees at maturity in terms of fuel, timber, fodder and other ecological services, besides soil enrichment. Similar results were also reported by Prabhu et al., (2002), Rajesh (2012) and Kumar et al., (2013).

In conclusion, from the study, it was inferred that integrated use of $75 \% \mathrm{RD} \mathrm{N}+$ 
$25 \% \mathrm{~N}$ through poultry manure and $100 \%$ $\mathrm{RDF}$ is the best nutrient management practice that can be adopted for agri-silvi system on par with sole crop, which was significantly superior over $75 \%$ RD N + $25 \% \mathrm{~N}$ through FYM, 75\% RD N $+25 \% \mathrm{~N}$ through Vermicompost, 75\% RD N + Azospirillum@ $5 \mathrm{~kg} \mathrm{ha}^{-1}, 75 \%$ RD N + PSB, $75 \% \mathrm{RD} \mathrm{N}+$ Azospirillum $+\mathrm{PSB}$ and control in red sandy loam soils to obtain better yields with high benefit cost ratio.

\section{Acknowledgement}

I (Ch. Pallavi) deem it as a great pleasure to express my heartfelt gratitude and respect to the chairman of my advisory committee, Dr. B. Joseph, Principal Scientist (Agronomy) and Head, RS \& RRS, Rudrur, PJTSAU and Dr. M. A. Aariff Khan, Principal Scientist (Soil Science), AICRP on Agroforestry, PJTSAU as a member of my Advisory Committee for his constructive encouragement in planning and execution of research work and Dr. S. Hemalatha, Principal Scientist (Agronomy), Farmers Call Centre, ANGRAU for her affectionate treatment during the course of investigation.

\section{References}

Basavaraju, T.B. and Purushotham, S. 2009. Integrated nutrient management in rainfed ragi (Eleusine coracana L. Gaertn.). Mysore J. Agri. Sci., 43: 366368.

Department of Agriculture and Cooperation. State of Indian Agriculture 20132014; Ministry of Agriculture, Government of India: New Delhi, India, 2014.

Deswal, A.K. and Nandal, D.P.S. 2008. Growth and yield of wheat (Triticum aestivum) under varying levels of irrigation and fertilizer in eucalyptus based agrisilviculture system. Indian J. Agroforestry, 10: 10-14.
Eyhorn, F., Ramakrishnan, $\mathrm{M}$ and Mader, $\mathrm{P}$. 2007. The variability of cotton based organic farming systems in India. Int. J. Agri. Sustainability, 5: 25-38.

Giribabu, B., Lather, M.M., Chandra Sekhar, K and Sankara Rao, V. 2010. Effect of nutrient management system on productivity of finger millet (Eleusine coracana L. Gaertn.) cultivars under sandy soils. The Andhra Agri. J., 57(1): 4-6.

Kumar, A., Kumar, M., Nandal, D.P.S. and Kaushik, N. 2013. Performance of wheat and mustard under Eucalyptus tereticornis based agri-silviculture system. Range Management and Agroforestry, 34: 192-195.

Narolia, R.S., Poonia, B.L and Yadav, R.S. 2009. Effect of vermicompost and inorganic fertilizers on productivity of pearl millet (Pennisetum glaucum). Indian J. Agri. Sci., 79(7): 506-509.

Patil, S.L., Sheelvantar, M.N and Lamani, V.K. 2003. Correlation analysis among growth and yield components of winter sorghum. International Sorghum and Millets Newsletter, ISMN, 44: 14-17, ICRISAT : 2003.

Prabhu, T., Narwadkar, P.R. and Sajindranath, A.K. 2002. Economics of integrated nutrient management in okra. J. Maharashtra Agri. Univ., 27: 316-318.

Prasad, J.V.N.S., Korwar, G.R., Rao, K.V., Srinivas, K., Srinivasarao, C.H., Peddababu, B., Venkateswarulu, B., Rao, S.N. and Kulkarni, H.D. 2011. On-farm evaluation of two fast growing trees for biomass production for industrial use in Andhra Pradesh, Southern India. New Forests, 42(1): 51-61.

Rajesh, P. 2012. Effect of pongamia green leaf manure and nitrogen levels on growth and yield of pearl millet (Pennisetum glaucum L.) in agri- 
silviculture system. M.Sc. (Ag) Thesis, Acharya N.G Ranga Agricultural University, Hyderabad.

Relyea, R.A. 2005. The impact of insecticides and herbicides on the biodiversity and productivity of aquatic communities. Ecol. Appli., 15: 618-627.

Singh, R.B. 2000. Environmental consequences of agricultural development: case study from the green revolution state of Haryana. Indian Agri. Ecosystem and Environ., 82: 97-103.

Sunitha, N., Ravi, V and Reddy, R. 2004. Nitrogen economy in finger millet through conjunctive use of organic manures and bio-fertilizers. Indian $J$. Dryland Agri. Res. Develop., 19(2): 172-174.

Umesh, M.R., Sharanappa, Shrinivasa, K.R. and Kumar, K.K.C. 2006. Effect of cropping systems and integrated nutrient management on growth, yield and nutrient uptake of finger millet under rainfed conditions. Crop Res., 31: 366-369.

Varalakshmi, L.R., Srinivasamurthy, C.A. and Bhaskar, S. 2005. Effect of integrated use of organic manures and inorganic fertilizers on organic carbon, available $\mathrm{N}, \mathrm{P}$ and $\mathrm{K}$ in sustaining productivity of groundnut-finger millet cropping system. J. Indian Soc. Soil Sci., 53: 315-318.

Yakadri, M. and Reddy, A.P.K., 2009. Productivity of pearl millet (Pennisetum glaucum L.) as influenced by planting pattern and nitrogen levels during summer. J. Res. ANGRAU, 37: 34-37.

\section{How to cite this article:}

Pallavi, Ch., B. Joseph, M.A. Aariff Khan and Hemalatha, S. 2016. Economic Evaluation of Finger Millet under different Nutrient Management Practices. Int.J.Curr.Microbiol.App.Sci. 5(8): 690-698. doi: http://dx.doi.org/10.20546/ijcmas.2016.508.078 